\title{
海水中の銅の同位体希䣋質量分析法 (I)
}

\author{
窒住 正世, 中村 精次, 伊藤 好二*
}

(1976 作 4 月 12 日受理)

\begin{abstract}
陚料溶液に ${ }^{65} \mathrm{Cu}$ スパイクを添加して同位体平衡を成立させてから銅をジチゾンークロロホルム中に 抽出する．銅を $6 \mathrm{~N}$ 塩酸中に逆抽出して蒸発乾固し，更に硝酸と過擝素酸とを添加してから完全に乾固 する。それを 1 滴の純水に溶解して試料とし，レニウムのシングルフィラメントをイオン源とする表面 電離質量分析法により， $I^{63} \mathrm{Cu}^{+} / I^{65} \mathrm{Cu}^{+}$を測定して銅含量を求めることができる。ただし $I^{63} \mathrm{Cu}^{+}$と ${ }^{165} \mathrm{Cu}^{+}$はそれぞれ ${ }^{63} \mathrm{Cu}^{+}$と ${ }^{65} \mathrm{Cu}^{+}$のイオンビームの強度である. イオン化時のシリカゲル・リン酸 安定凨の量比を検討し，感度を既報1の 10 倍の $10^{-11} \mathrm{~g}$ に上昇させることができた。

海水試料 $50 \mathrm{~g}$ に $0.1 \mu \mathrm{g}$ の ${ }^{65} \mathrm{Cu}$ スパイクを添加した場合に， ${ }^{10-15} \mathrm{~A} の I^{65} \mathrm{Cu}^{+}$を得ることがで き, $I^{63} \mathrm{Cu}^{+} / I^{65} \mathrm{Cu}^{+}$の変動係数は $(0.3 \sim 1.5) \%$ であった. 数十 ng の銅量の繰り返し分析の分析精度 は誤差 $3 \%$ 程度であり, 又海水の溶存成分による影響は認められなかった。本法は实験に用いる純水, 各種試薬溶液中の銅定量にも応用できる.
\end{abstract}

1 原理, 目的及び概要

塩酸を添加して酸性とした海水試料化 ${ }^{65} \mathrm{Cu}$ 濃縮スパ イク溶液を加えて試料中の銅との間汇同位体平衡を成立 させる。

${ }^{63} \mathrm{Cu} /{ }^{65} \mathrm{Cu}=\left\{x \cdot 63 \mathrm{f}+{ }^{63} \mathrm{Cu}(\mathrm{S})\right\} /\left\{x \cdot 65 \mathrm{f}+{ }^{65} \mathrm{Cu}(\mathrm{S})\right\}$

$x$ 核試料中の銅のモル数, ${ }^{63} \mathrm{f}$ と ${ }^{65 \mathrm{f}}$ は試料中の銅がもと もと有している ${ }^{63} \mathrm{Cu}$ と ${ }^{65} \mathrm{Cu} の$ のすなわ方普通銅の同 位体存在度, ${ }^{63} \mathrm{Cu}(\mathrm{S})$ と ${ }^{65} \mathrm{Cu}(\mathrm{S})$ はスパイクとして添 加したモル数である. ${ }^{65} \mathrm{Cu}$ 濃縮スパイク溶液中には原 子比で $0.30 \%$ の ${ }^{63} \mathrm{Cu}$ が含まれている1). 左边の ${ }^{63} \mathrm{Cu} /$ ${ }^{65} \mathrm{Cu}$ 它知れば， $x$ を求めることができる1).

ジチゾン・クロロホルムを用いて銅を抽出して酸処理 をし蒸発乾固し無機壏とする. 1 滴の脱イオン水に溶解 して質量分析用試料とする. 質量分析計は日立 RMU 6 型で，イオン源はレニウムのシングルフィラメントであ り，イオン化時の安定剂としてシリカゲルとリン酸を用 いた. ${ }^{63} \mathrm{Cu}^{+}$と ${ }^{65} \mathrm{Cu}^{+}$のイオンビームの強度 $\left[{ }^{63} \mathrm{Cu}^{+}\right.$,

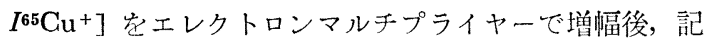
録用紙にペン記録する。記録紙のピークの $1 \mathrm{~V}$ は, $10^{-15} \mathrm{~A}$ の $I \mathrm{Cu}+$ に相当する. $I^{63} \mathrm{Cu}^{+} / I^{65} \mathrm{Cu}^{+}$の值にエレ クトロンマルチプライヤーの質量効果の補正をして $\{$ 寸

* 室蘭工業大学工業化学科工業分析化学教室 : 北海道 室蘭市水元町 27
市わち，(63/65) $)^{1 / 2}$ 老乘じ\}， ${ }^{63} \mathrm{Cu} /{ }^{65} \mathrm{Cu}$ 觉求为，式 (1) に代入して $x$ の值杂得ることができる.フィラメント上 の $1 \mu \mathrm{g}$ の銅より $\left(10^{-15} \sim 10^{-13}\right) \mathrm{A}$ の $I \mathrm{Cu}+$ 唯られ, 最低 $10^{-11} \mathrm{~g}$ の銅が検出できる. $I^{63} \mathrm{Cu}^{+} / I^{65} \mathrm{Cu}^{+}$の測定 精度は変動係数として， ${ }^{65} \mathrm{Cu}$ スパイクの場合で $(0.8$ 3) \%，普通銅で $0.3 \%$ 程度である.

さて既報1)では，供試海水量として $(0.5 \sim 1) \mathrm{kg}$ 孛用 い，そのゆに含有される $(0.2 \sim 0.4) \mu \mathrm{g}$ の銅を分析対象 とした。しかし供試量が少量で済めば，i）貴重な試料 の節約ができ地球化学的に有利であり, ii) 分析化学的 には, 試料調製のための試薬量が少昂で済み, 又容器, 用具も小型で済むからブランク值㤂下げることができ る.このことは精度を落とすことなく感度を上げること によって実現できることである，具体的にはイオン源フ ィラメント上にローディングす句銅量をなるべく少量で 済をせ，しかもそれから必要十分な強度と安定性のある $I \mathrm{Cu}+$ を発生させなければならないそのために，i）

$\mathrm{Cu}^{+}$発生の際に安定剂として作用するシリカゲルとリ ン酸の量と比の検討， ii) イオン源フィラメント上にロ ーディングする銅化命物の㢅劣試検，iii）同位体効果， メモリ一効果の程度についての検討，iv）ブランク值を 低下させる手段の検討など名積み重极た。

その結果, 供試海水量は $50 \mathrm{~g}$ 程度で济むようになっ

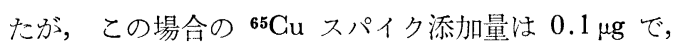
$I^{63} \mathrm{Cu}^{+} / I^{65} \mathrm{Cu}^{+}$の変動係数も $1.5 \%$ 以内で定量が可能と なった.この方法で求めた相模湾海水の銅濃度は $(0.34$ 
土0.01) $\mathrm{ppb},(0.30 \pm 0.01) \mathrm{ppb}$ であり,太平洋黑潮外 洋の深海水では $(0.33 \pm 0.02) \mathrm{ppb}$ であった。

$$
2 \text { 实験 }
$$

\section{$2 \cdot 1 \mathbf{C u}^{+}$発生時の安定剤, シリカゲルとリン酸量}

イオン源レニウムフィシメントに銅化合物だけをロー ディングしても $\mathrm{Cu}^{+}$のイオンビームを発生させること は難しいが，シリカゲルとリン酸）壱添加すると強く安 定なイオンビームを得ることができる1). シリカゲルと リン酸の量と比が, $\mathrm{Cu}+$ イオン発生に及ぼす効果を ${ }^{65} \mathrm{Cu}$ 濃縮スパイク溶液（硝酸酸性溶液， ${ }^{65} \mathrm{Cu}$ として $1 \mu \mathrm{g}$ ） を用いて検討し，その結果を Table 1 に示した。

イオン源フィラメント電流值が $0.9 \mathrm{~A}$ 程度になると $\mathrm{Cu}^{+}$の発生が始まり，(1.2 1.4) A で $I \mathrm{Cu}+$ は $\left(10^{-15}\right.$ 〜10-14) A に達する. 更にフィラメント電流值を上昇 させると，ICu+ も増大するが不安定となって $1.6 \mathrm{~A}$ を 越えると急激に減赇してしまうのが一般的傾向である.

同一フィラメント電流值でも $I^{65} \mathrm{Cu}^{+}$の動摇が激しい場 合があるが，ベーキングにより定常化させることができ る.シリカゲルとリン酸の量と比老適当に選択すると， $I^{65} \mathrm{Cu}^{+}$が $10^{-14} \mathrm{~A}$ 程度の安定なイオンビームを，すな わち既報1)に比べ 10 倍の強度のビーム党得ることがで きる。この場合の $I^{63} \mathrm{Cu}^{+} / I^{65} \mathrm{Cu}^{+}$は 0.003 程度である が，その变動係数は $(0.8 〜 3.0) \%$ となった.シリカゲ
ル・リン酸の量と比の有効範囲は広いことがわかった が，本法では $12 \mu \mathrm{g}$ と $87 \mu \mathrm{g}, 18 \mu \mathrm{g}$ と $131 \mu \mathrm{g}$ の組み合 わせを主として測定を進めた。

なお，普通銅の測定の变動係数は $0.3 \%$, Table 3, 試薬分析では $(0.4 \sim 2.2) \%$, Table 6, そして海水分析 で $(0.3 \sim 1.5) \%$, Table 7 であった.

\section{$2 \cdot 2$ イオン源銅化合物の種類}

イオン源フィラメント上にローディングする銅化合物 と，それより発生する $I \mathrm{Cu}^{+}$について検討した. ${ }^{65} \mathrm{Cu}$ として $2 \mu \mathrm{g}$ 相当の ${ }^{65} \mathrm{Cu}$ 濃縮スパイク溶液に過塩素酸, 硫酸, 硝酸, 塩酸, リン酸など各種の酸を加えて窒素気 流中で蒸発乾固を繰り返した後に，1滴の脱イオン水に 溶解して質量分析用試料としその結果は Table 2 に示 した. いずれの場合もフィラメント電流值 $1.2 \mathrm{~A}$ 程度で $10^{-14} \mathrm{~A}$ の安定な $I^{65} \mathrm{Cu}^{+}$が得られ， $I^{63} \mathrm{Cu}^{+} / I^{65} \mathrm{Cu}^{+}$の 変動係数も（1.1〜2.5)\%の範囲であった. 同様な検討 を普通銅（ ${ }^{63} \mathrm{Cu}=0.68 \mu \mathrm{g} ，{ }^{65} \mathrm{Cu}=0.30 \mu \mathrm{g} ）$ を対象として 行ったが. いずれの化合物よりも質量分析に十分な強度 と安定なイオンビームを得ることができた.

すなわち，イオン源にローディングする銅化合物の種 類については，硫酸塩が良いという経験はあるが1)，特 定のもの黉定しなければならぬほどの差は見いだせな かった．安定剂として添加してある過剩のリン酸が，銅

Table 1 Stabilizing agents for ${ }^{65} \mathrm{Cu}^{+}$emission from $1 \mu \mathrm{g}$ of ${ }^{65} \mathrm{Cu}$ spike

\begin{tabular}{|c|c|c|c|c|c|c|c|c|}
\hline \multirow{2}{*}{$\begin{array}{l}\text { Test } \\
\text { No. }\end{array}$} & \multicolumn{2}{|c|}{ Stabilizer $(\mu \mathrm{g})$} & \multirow{2}{*}{$\begin{array}{c}I^{65} \mathrm{Cu}^{+} \dagger \\
\left(10^{-15} \mathrm{~A}\right)\end{array}$} & \multirow{2}{*}{$\begin{array}{l}\text { Ion source } \\
\text { filament } \\
\text { current }{ }^{+}+ \\
\text {(A) }\end{array}$} & \multirow{2}{*}{$I^{63} \mathrm{Cu}^{+} / I^{65} \mathrm{Cu}^{+}$} & \multirow{2}{*}{$\begin{array}{l}\text { C. } \mathrm{V} . \mathrm{f}^{+\dagger}+ \\
(\%)\end{array}$} & \multirow{2}{*}{$\begin{array}{c}\operatorname{Max} . I^{65} \mathrm{Cu}^{+} \\
\left(10^{-15} \mathrm{~A}\right)\end{array}$} & \multirow{2}{*}{$\begin{array}{c}\text { Ion source } \\
\text { filament } \\
\text { current } \\
\text { (A) }\end{array}$} \\
\hline & Silica gel as $\mathrm{SiO}_{2}$ & $\mathrm{H}_{3} \mathrm{PO}_{4}$ & & & & & & \\
\hline 1 & 12 & 87 & $4 \sim 5$ & 1.250 & 0.00300 & 3.0 & 11 & 1.258 \\
\hline 2 & 3 & 131 & $10 \sim 17$ & 1.180 & 0.00300 & 1.7 & 18 & 1.180 \\
\hline 3 & 6 & 131 & $30 \sim 60$ & 1.310 & 0.00298 & 0.8 & 183 & 1.700 \\
\hline 4 & 9 & 131 & $23 \sim 31$ & 1.200 & 0.00296 & 1.2 & 318 & 1.500 \\
\hline 5 & 12 & 131 & $51 \sim 64$ & 1.310 & 0.00300 & 1.0 & 134 & 1.440 \\
\hline 6 & 18 & 131 & $129 \sim 148$ & 1.560 & 0.00298 & 2.0 & 162 & 1.560 \\
\hline 7 & 12 & 174 & $8 \sim 18$ & 1.320 & 0.00297 & 1.4 & 134 & 1.310 \\
\hline
\end{tabular}

$\dagger$ Ion beam intensity of ${ }^{65} \mathrm{Cu}^{+}$; † Optimum intensity for $\mathrm{Cu}^{+}$emission; †⿰亻 Coefficient of variation in measurement of $\mathrm{I}^{63} \mathrm{Cu}^{+} /$ $I^{65} \mathrm{Cu}^{+}$

Table $2 \mathrm{Cu}^{+}$emission from copper compounds

\begin{tabular}{|c|c|c|c|c|c|c|c|c|c|c|c|c|}
\hline \multirow{2}{*}{ Copper tested } & \multirow{2}{*}{$\begin{array}{l}\text { Test } \\
\text { No. }\end{array}$} & \multirow{2}{*}{$\begin{array}{l}\text { Compound } \\
\text { loaded }\end{array}$} & \multirow{2}{*}{\multicolumn{2}{|c|}{$\begin{array}{c}I^{65} \mathrm{Cu}^{+} \\
\left(10^{-15} \mathrm{~A}\right)\end{array}$}} & \multirow{2}{*}{$\begin{array}{l}\text { Optimum } \\
\text { filament } \\
\text { current } \\
\text { (A) }\end{array}$} & \multirow{2}{*}{$I^{63} \mathrm{Cu}^{+} / I^{65} \mathrm{Cu}^{+}$} & \multirow{2}{*}{ C. V. } & \multirow{2}{*}{$n \dagger$} & \multirow{2}{*}{$\begin{array}{c}\operatorname{Max} .1^{65} \mathrm{Cu}^{+} \\
\left(10^{-15} \mathrm{~A}\right)\end{array}$} & \multirow{2}{*}{$\begin{array}{l}\text { Filament } \\
\text { current } \\
\text { (A) }\end{array}$} & \multicolumn{2}{|c|}{ Stabilizer $(\mu \mathrm{g})$} \\
\hline & & & & & & & & & & & Silica gel & $\mathrm{H}_{3} \mathrm{PO}_{4}$ \\
\hline $\begin{array}{l}\text { Spike }{ }^{65} \mathrm{Cu} \\
{ }^{65} \mathrm{Cu}-2 \mu \mathrm{g}\end{array}$ & $\left\{\begin{array}{l}1 \\
2 \\
3 \\
4 \\
5\end{array}\right.$ & $\begin{array}{l}\mathrm{Cu}\left(\mathrm{ClO}_{4}\right)_{2} \\
\mathrm{CuSO} \mathrm{O}_{4} \\
\mathrm{Cu}\left(\mathrm{NO}_{3}\right)_{2} \\
\left.\mathrm{CuCl}_{2}\right)_{2} \\
\mathrm{Cu}_{3}\left(\mathrm{PO}_{4}\right)_{2}\end{array}$ & $\begin{array}{r}49 \\
30 \\
13 \\
12 \\
6\end{array}$ & $\begin{array}{l}\sim 38 \\
\sim 47 \\
\sim 16 \\
\sim 15 \\
\sim 10\end{array}$ & $\begin{array}{l}1.240 \\
1.228 \\
1.200 \\
1.200 \\
1.225\end{array}$ & $\begin{array}{l}0.00304 \\
0.00306 \\
0.00297 \\
0.00299 \\
0.00308\end{array}$ & $\begin{array}{l}1.1 \\
1.2 \\
1.5 \\
1.4 \\
2.5\end{array}$ & $\begin{array}{l}7 \\
7 \\
7 \\
7 \\
7\end{array}$ & $\begin{array}{r}90 \\
820 \\
93 \\
102 \\
52\end{array}$ & $\begin{array}{l}1.320 \\
1.720 \\
1.500 \\
1.220 \\
1.440\end{array}$ & $\begin{array}{l}12 \\
12 \\
12 \\
12 \\
12\end{array}$ & $\begin{array}{r}87 \\
131 \\
87 \\
87 \\
131\end{array}$ \\
\hline $\begin{array}{l}\text { Common Cu } \\
\qquad{ }^{65} \mathrm{Cu}=0.3 \mu \mathrm{g}\end{array}$ & $\left\{\begin{array}{r}6 \\
7 \\
8 \\
9 \\
10\end{array}\right.$ & $\begin{array}{l}\mathrm{Cu}\left(\mathrm{ClO}_{4}\right)_{2} \\
\mathrm{CuSO} \mathrm{SO}_{4} \\
\mathrm{Cu}\left(\mathrm{NO}_{3}\right)_{2} \\
\mathrm{CuCl}_{2} \\
\mathrm{Cu}_{3}\left(\mathrm{PO}_{4}\right)_{2}\end{array}$ & & $\begin{array}{l}6 \sim 6.9 \\
6 \sim 6.8 \\
6 \sim 6.4 \\
9 \sim 7.7 \\
8 \sim 6.9\end{array}$ & $\begin{array}{l}1.240 \\
1.115 \\
1.250 \\
1.200 \\
1.150\end{array}$ & $\begin{array}{l}2.283 \\
2.282 \\
2.275 \\
2.283 \\
2.252\end{array}$ & $\begin{array}{l}0.3 \\
0.5 \\
0.4 \\
0.4 \\
0.4\end{array}$ & $\begin{array}{r}11 \\
11 \\
7 \\
11 \\
11\end{array}$ & $\begin{array}{l}99 \\
22 \\
13 \\
12 \\
28\end{array}$ & $\begin{array}{l}1.610 \\
1.420 \\
1.560 \\
1.400 \\
1.420\end{array}$ & $\begin{array}{l}12 \\
12 \\
12 \\
12 \\
12\end{array}$ & $\begin{array}{r}87 \\
87 \\
87 \\
87 \\
131\end{array}$ \\
\hline
\end{tabular}

$\dagger$ Number of $I^{6}{ }^{3} \mathrm{Cu}^{+} / I^{65} \mathrm{Cu}^{+}$set 
Table $3 \mathrm{Cu}^{+}$emission and isotope effect

\begin{tabular}{|c|c|c|c|c|c|c|c|c|}
\hline $\mathrm{Cu}$ loaded & $\begin{array}{l}\text { Test } \\
\text { No. }\end{array}$ & $\begin{array}{c}I^{65} \mathrm{Cu}^{+} \\
\left(10^{-15} \mathrm{~A}\right)\end{array}$ & $\begin{array}{l}\text { Filament } \\
\text { current } \\
(A)\end{array}$ & $I^{53} \mathrm{Cu}^{+} / I^{65} \mathrm{Cu}^{+}$ & $\sigma \dagger$ & $\stackrel{(\%)}{(\%)}$ & $n$ & $\begin{array}{l}\text { Reording time } \\
(\min )\end{array}$ \\
\hline $\begin{array}{l}\text { Spike Cu } \\
\qquad{ }^{6} \mathrm{Cu}=1 \mu \mathrm{g}\end{array}$ & 1 & $\begin{array}{r}3.6 \sim 5.5 \\
6.9 \sim 8.2 \\
15.6 \sim 17.9 \\
31.1 \sim 64.2\end{array}$ & $\begin{array}{l}1.050 \\
1.100 \\
1.180 \\
1.310\end{array}$ & $\begin{array}{l}0.00300 \\
0.00300 \\
0.00300 \\
0.00300\end{array}$ & $\begin{array}{l}0.00003 \\
0.00005 \\
0.00002 \\
0.00003\end{array}$ & $\begin{array}{l}1.1 \\
1.8 \\
0.6 \\
0.9\end{array}$ & $\begin{array}{l}7 \\
7 \\
7 \\
7\end{array}$ & $\begin{array}{l}63 \\
32 \\
79 \\
+1\end{array}$ \\
\hline $\begin{array}{l}\text { Spike Cu } \\
\qquad{ }^{65} \mathrm{Cu}=1 \mu \mathrm{g}\end{array}$ & 2 & $\begin{array}{r}9.8 \sim 13.9 \\
14.4 \sim 20.3 \\
29.5 \sim 60.2 \\
44.8 \sim 60.2\end{array}$ & $\begin{array}{l}1.110 \\
1.160 \\
1.310 \\
1.350\end{array}$ & $\begin{array}{l}0.00297 \\
0.00299 \\
0.00298 \\
0.00297\end{array}$ & $\begin{array}{l}0.00002 \\
0.00005 \\
0.00002 \\
0.00007\end{array}$ & $\begin{array}{l}0.5 \\
1.7 \\
0.8 \\
2.3\end{array}$ & $\begin{array}{l}7 \\
7 \\
7 \\
7\end{array}$ & $\begin{array}{l}62 \\
45 \\
46 \\
40\end{array}$ \\
\hline $\begin{array}{l}\text { Common } \mathrm{Cu} \\
{ }^{6} \mathrm{Cu}=0.30 \mu \mathrm{g} \\
{ }^{6} \mathrm{Cu}=0.68 \mu \mathrm{g}\end{array}$ & 3 & $\begin{array}{r}1.6 \sim 2.0 \\
5.1 \sim 6.9 \\
13.7 \sim 20.5\end{array}$ & $\begin{array}{l}1.120 \\
1.200 \\
1.320\end{array}$ & $\begin{array}{l}2.280 \\
2.282 \\
2.276\end{array}$ & $\begin{array}{l}0.007 \\
0.006 \\
0.007\end{array}$ & $\begin{array}{l}0.3 \\
0.3 \\
0.3\end{array}$ & $\begin{array}{l}11 \\
11 \\
11\end{array}$ & $\begin{array}{l}70 \\
70 \\
70\end{array}$ \\
\hline
\end{tabular}

$\uparrow$ Standard deviation

塩の化学形による相違を消去していると考えられる．既 報1)では硫酸塩を利用したが，精製の困難な硫酸の使用 を避けて，硝酸と過塭素酸を添加して弥発乾固したもの を脱イオン水に溶解して質量分析用試料とすることとし た。

\section{3 同位体効果，メモリ一効果}

2.3.1 同位体効果 ${ }^{65} \mathrm{Cu}$ スパイクの場合は $1 \mu \mathrm{g}$, 普通銅の場合は ${ }^{63} \mathrm{Cu} ，{ }^{65} \mathrm{Cu}$ のそれぞれ $0.68 \mu \mathrm{g} ， 0.30 \mu \mathrm{g}$ 相当量をローディングして，イオンビーム強度と $I^{63} \mathrm{Cu}^{+}$ $/ I^{65} \mathrm{Cu}^{+}$の経時的関係を検討した (Table 3). Test No.

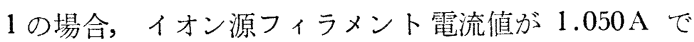
$I^{65} \mathrm{Cu}+$ は $3.6 \times 10^{-15} \mathrm{~A}$ となった後, 自然に伸張を続 け，3 時間後に $5.5 \times 10^{-15} \mathrm{~A}$ に達した. この間， $I^{63} \mathrm{Cu}^{+}$ $/ I^{65} \mathrm{Cu}^{+}$の 1 測定に 5 ないし 10 分間をかけ 7 測定をし たが, 平均值は 0.00300 で变動係数は $1.1 \%$ であった。 フィラメント電流值を段階的に $1.100 \mathrm{~A}, 1.180 \mathrm{~A}$, $1.310 \mathrm{~A}$ と上昇させ同様の測定を行ったが，各回ごとの 平均值は変わらず，規則的ないし系統的な変化は認めら れなかった．同位体効果は变動係数の中に含まれてしま う程度のものと考えられる. Test No. 3 の普通銅の場 合も同様である. 従って本法では, イオン源フィラメン 卜電流值の高低, $\mathrm{ICu}^{+}$の強弱にかかわらず， $I^{63} \mathrm{Cu}^{+} /$ $I^{65} \mathrm{Cu}^{+}$の測定を行い，同位体効果は無視した。

2.3.2 メモリー効果 前回の測定終了後, 新しいイ オン源フィラメントを使用して電流值を $0 \mathrm{~A}$ より $3 \mathrm{~A}$ まで上げてイオン源部を加温しても，その間 $\mathrm{ICu}^{+} か ゙$ 認

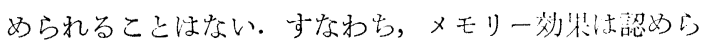
れなかった。

\section{$2.4 I^{63} \mathbf{C u}^{+} / \boldsymbol{I}^{65} \mathbf{C u}^{+}$の繰り返し分析と同位体比}

${ }^{65} \mathrm{Cu}$ スパイクについては $1 \mu \mathrm{g}$ と $0.5 \mu \mathrm{g}$ ，普通銅では ${ }^{65} \mathrm{Cu}$ 相当量として $0.30 \mu \mathrm{g}$ と $0.15 \mu \mathrm{g}$ をローディング して繰り返し分析を行い，その結果を Table 4 に示し
Table 4 Replicate analysis of $I^{63} \mathrm{Cu}^{+} / I^{65} \mathrm{Cu}^{+}$ from spike and common copper

\begin{tabular}{|c|c|c|c|c|}
\hline & $\begin{array}{l}\text { Test } \\
\text { No. }\end{array}$ & $\begin{array}{r}{ }^{65} \mathrm{Cu} \\
\text { loaded } \\
(\mu \mathrm{g})\end{array}$ & ${ }_{\text {measured }}^{I^{63} \mathrm{Cu}^{+} / I^{55} \mathrm{Cu}^{+}}$ & $\begin{array}{c}I^{53} \mathrm{Cu}^{+} / I^{65} \mathrm{Cu}^{+} \\
\text {average }\end{array}$ \\
\hline $\begin{array}{l}\text { Spike }{ }^{65} \mathrm{Cu} \\
\text { imported from } \\
\text { O. R. N. L. }+ \\
\text { and dissolved } \\
\text { in } \mathrm{HNO}_{3}\end{array}$ & $\left\{\begin{array}{l}1 \\
2 \\
3 \\
4 \\
5 \\
6\end{array}\right.$ & $\begin{array}{l}1 \\
1 \\
1 \\
1 \\
1 \\
0.5\end{array}$ & $\begin{array}{l}0.00294 \pm 0.00004 \\
0.00300 \pm 0.00004 \\
0.00298 \pm 0.00005 \\
0.00300 \pm 0.00003 \\
0.00302 \pm 0.00002 \\
0.00304 \pm 0.00002\end{array}$ & $0.00300 \pm 0.00004$ \\
\hline $\begin{array}{l}\text { Common Cu } \\
\text { (99.999\% com- } \\
\text { mercial metal } \\
\text { was dissolved } \\
\text { in } \mathrm{HNO}_{3} \text { ) }\end{array}$ & $\left\{\begin{array}{r}7 \\
8 \\
9 \\
10 \\
11 \\
12 \\
13\end{array}\right.$ & $\begin{array}{l}0.3 \\
0.3 \\
0.3 \\
0.3 \\
0.3 \\
0.15 \\
0.15\end{array}$ & 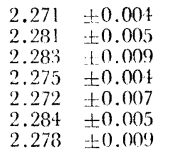 & $2.273 \pm 0.005$ \\
\hline
\end{tabular}

$\dagger$ Oak Ridge National Laboratory, Tenu., U.S.A.

た. $I^{63} \mathrm{Cu}^{+} / I^{65} \mathrm{Cu}^{+}$は ${ }^{65} \mathrm{Cu}$ スパイクで 0.00300 土 0.00004，曾通銅で 2.278士0.005 の简精度で测定でき た。

${ }^{63} \mathrm{Cu} /{ }^{65} \mathrm{Cu}$ の値(原子比)は，エレクトロンマルチプラ イヤ一使用による補正值 $(63 / 65)^{1 / 2}=0.9845$ 岩 $I^{63} \mathrm{Cu}^{+} /$ $I^{65} \mathrm{Cu}^{+}$の值に烡じ， ${ }^{65} \mathrm{Cu}$ では $0.00295 \pm 0.00004$ ，普 通銅で $2.243 \pm 0.005$ となった (Table 5). すなわ方, ${ }^{65} \mathrm{Cu}$ の同位体存在度 ${ }^{65} \mathrm{f}$ は，とれぞれ 0.997 と 0.308 である・

Table 5 Isotope abundance of spike and common copper

\begin{tabular}{|c|c|c|c|c|}
\hline & $\underset{\text { measured }}{I^{63} \mathrm{Cu}^{+} / I^{65} \mathrm{Cu}^{+}}$ & $\begin{array}{c}{ }^{63} \mathrm{Cu} /{ }^{65} \mathrm{Cu} \dagger \\
\text { corrected }\end{array}$ & $\begin{array}{c}\text { Isotope } \\
{ }_{63} \mathrm{Cu}\end{array}$ & $\underset{65 \mathrm{Cu}}{\Delta \text { dbundancet }^{-}}$ \\
\hline Spike ${ }^{65} \mathrm{Cu}$ & $0.00300 \pm 0.00004$ & $0.00295 \pm 0.00004$ & 0.003 & 0.997 \\
\hline Common $\mathrm{Cu}$ & $2.278 \pm 0.005$ & $2.243 \pm 0.005$ & 0.692 & 0.308 \\
\hline
\end{tabular}

3 試薬，純水中の銅の定量

本法の応用性を酸，純水中の銅定量によって検討し た. Table 6 に表示した硫酸その他の酸及び純水を，そ 
Table 6 Determination of copper in chemical reagents and clean water

\begin{tabular}{|c|c|c|c|c|c|c|c|c|c|}
\hline Sample & $\begin{array}{c}\text { Samplc } \\
\text { taken } \\
(\mathrm{g})\end{array}$ & $\begin{array}{c}{ }^{65} \mathrm{Cu} \text { spike } \\
\text { added } \\
(\mu \mathrm{g})\end{array}$ & $\left(\begin{array}{c}1^{65} \mathrm{Cu}^{+} \\
\left(10^{-15} \mathrm{~A}\right)\end{array}\right.$ & $\begin{array}{l}\text { Filarnent } \\
\text { current } \\
\text { (A) }\end{array}$ & $\begin{array}{c}I^{63} \mathrm{Cu}^{+} / I^{65} \mathrm{Cu}^{+} \\
\text {measured }\end{array}$ & $\begin{array}{l}\text { C. V. } \\
(\%)\end{array}$ & $\begin{array}{c}{ }^{63} \mathrm{Cu} /{ }^{65} \mathrm{Cu} \\
\text { corrected }\end{array}$ & $\begin{array}{l}\text { Copper } \\
\text { measured } \\
\quad(n g)\end{array}$ & $\begin{array}{l}\text { Copper } \\
\text { concn. } \\
\text { (ppb) }\end{array}$ \\
\hline conc. $\mathrm{H}_{2} \mathrm{SO}_{4}$ & 5.96 & 0.523 & 2.0 & 1.410 & 0.0322 & 0.9 & 0.0317 & 21.5 & 3.61 \\
\hline conc. $\mathrm{HNO}_{3}$ & 19.8 & 0.519 & 6.2 & 1.230 & 0.00555 & 1.5 & 0.00546 & 1.84 & 0.09 \\
\hline $6 \mathrm{~N} \mathrm{HCl}$ & 20.0 & 0.526 & 3.5 & 1.330 & 0.00374 & 2.2 & 0.00368 & 0.54 & 0.03 \\
\hline $12 \mathrm{~N} \mathrm{HCl}(\mathrm{A})$ & 15.4 & 0.524 & 13.7 & 1.500 & 0.00527 & 0.4 & 0.00519 & 1.65 & 0.11 \\
\hline $12 \mathrm{~N} \mathrm{HCl}(\mathrm{B})$ & 12.7 & 1.05 & 11.7 & 1.340 & 0.00431 & 1.0 & 0.00424 & 1.91 & 0.15 \\
\hline $60 \% \mathrm{HClO}_{4}(\mathrm{C})$ & 4.91 & 0.520 & 22.2 & 1.380 & 0.00525 & 1.7 & 0.00517 & 1.63 & 0.33 \\
\hline $60 \% \mathrm{HClO}_{4}(\mathrm{D})$ & 9.85 & 0.506 & 3.7 & 1.200 & 0.00526 & 1.3 & 0.00518 & 1.59 & 0.16 \\
\hline Clcan water & 40.1 & 0.526 & 6.9 & 1.105 & 0.0185 & 0.8 & 0.0182 & 11.4 & 0.284 \\
\hline " & 80.2 & 0.527 & 3.8 & 1.210 & 0.0348 & 0.6 & 0.0348 & 24.0 & 0.299 \\
\hline
\end{tabular}

Table 7 Determination of copper in sea water

\begin{tabular}{|c|c|c|c|c|c|c|c|c|}
\hline Sample & $\begin{array}{c}\text { Amount of } \\
\text { sample analyzed } \\
(\mathrm{g})\end{array}$ & $\begin{array}{c}I^{65} \mathrm{Cu}^{+} \\
\left(10^{-15} \mathrm{~A}\right)\end{array}$ & $\begin{array}{l}\text { Filament } \\
\text { current } \\
\text { (A) }\end{array}$ & $\underset{\text { measured }}{I^{63} \mathrm{Cu}^{+} / I^{65} \mathrm{Cu}^{+}}$ & $\begin{array}{l}\text { C. V. } \\
(\%)\end{array}$ & $\begin{array}{l}{ }^{63} \mathrm{Cu} /{ }^{65} \mathrm{Cu} \\
\text { corrected }\end{array}$ & $\underset{\substack{\mathrm{Cu} \\
\text { measured }}}{(\mathrm{ng})}$ & $\begin{array}{l}\mathrm{Cu} \\
\text { concn. } \\
(\mathrm{ppb})\end{array}$ \\
\hline $\begin{array}{l}\text { Sagami bay water A ( } 10 \mathrm{~m} \text { deep }) \\
1.863 \mathrm{~kg} \text { of sea water spiked } \\
\text { with } 4.26 \mu \mathrm{g} \text { of } 65 \mathrm{Cu}\end{array}$ & $\begin{array}{r}51 \\
51 \\
102 \\
102\end{array}$ & $\begin{array}{l}0.51 \\
0.52 \\
0.59 \\
1.24\end{array}$ & $\begin{array}{l}1.260 \\
1.200 \\
1.220 \\
1.290\end{array}$ & $\begin{array}{l}0.129 \\
0.126 \\
0.118 \\
0.114\end{array}$ & $\begin{array}{l}0.9 \\
0.5 \\
0.3 \\
0.3\end{array}$ & $\begin{array}{l}0.127 \\
0.124 \\
0.114 \\
0.112\end{array}$ & $\begin{array}{l}21.6 \\
21.1 \\
39.2 \\
37.7\end{array}$ & $\begin{array}{l}0.34 \\
0.34 \\
0.33 \\
0.35\end{array}$ \\
\hline $\begin{array}{l}\text { Sagami bay water B }(10 \mathrm{~m} \text { deep }) \\
3.093 \mathrm{~kg} \text { of sea water spiked } \\
\text { with } 4.26 \mu \mathrm{g} \text { of } 65 \mathrm{Cu}\end{array}$ & $\begin{array}{r}51 \\
102 \\
102\end{array}$ & $\begin{array}{l}1.18 \\
0.46 \\
0.65\end{array}$ & $\begin{array}{l}1.220 \\
1.330 \\
1.270\end{array}$ & $\begin{array}{l}0.180 \\
0.169 \\
0.168\end{array}$ & $\begin{array}{l}0.4 \\
0.7 \\
0.7\end{array}$ & $\begin{array}{l}0.177 \\
0.166 \\
0.165\end{array}$ & $\begin{array}{l}18.7 \\
34.9 \\
34.7\end{array}$ & $\begin{array}{l}0.29 \\
0.30 \\
0.31\end{array}$ \\
\hline $\begin{array}{l}\text { Central pacific water }(1000 \mathrm{~m} \text { deep }) \\
2.730 \mathrm{~kg} \text { of sea water spiked } \\
\text { with } 4.26 \mu \mathrm{g} \text { of } 65 \mathrm{Cu}\end{array}$ & $\begin{array}{r}51 \\
102 \\
153\end{array}$ & $\begin{array}{l}0.27 \\
0.67 \\
3.75\end{array}$ & $\begin{array}{l}1.200 \\
1.300 \\
1.320\end{array}$ & $\begin{array}{l}0.174 \\
0.169 \\
0.149\end{array}$ & $\begin{array}{l}1.1 \\
1.5 \\
0.6\end{array}$ & $\begin{array}{l}0.171 \\
0.166 \\
0.147\end{array}$ & $\begin{array}{l}20.4 \\
39.5 \\
51.9\end{array}$ & $\begin{array}{l}0.32 \\
0.35 \\
0.31\end{array}$ \\
\hline
\end{tabular}

れぞれテフロンビーカーけに星りとり， ${ }^{65} \mathrm{Cu}$ 濃縮スパ イク溶液をマイクロピペットで加劣る。等素気流中で完 全に蒸発乾国してから1滴の脱イオン水に溶かし，質晊 分析用試料とする.

硫酸は市販特級品であり，その他の酸は沛贩特級品を 石英製装置で再蒸留してから哑製した，純水は市水道水 をスズめっき銅製装置で蒸留してから石英 2 段式装置で 蒸留することにより，こん跡の銅成分望含有するもので ある.

分析に祳厚な酸であるための障啙はなく, $I \mathrm{Cu}^{+}$も 安定で， $I^{63} \mathrm{Cu}^{+} / I^{65} \mathrm{Cu}^{+}$の变動係数も 2.4 项の基碟実 験の範四内であった。

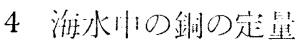

\section{1 試料びん}

41 容量の白他細日のホリエチレンびんの外外をセ トンで洗った後, 濃硝酸小に一些伩汶してから脱イオン 水で洗液が性になるまで洗っておく、びん川の空気を アルゴンで瑥換した後に，とれぞれのびん小に $20.0 \mathrm{ml}$ ずつの 14 N硝酸（Table 6) 在昆り入れ，密咕んす. ホリエチレン袋に三重に封じ，木箱に収めて輸送した。

\section{2 試料, スパイク添加}

試料は東京大学海洋研の堀部純男, 坪田博行によって 相模湾中央の海面下 $10 \mathrm{~m}$ と, 黑潮外洋太平洋の海面下
$1000 \mathrm{~m}$ より採取された。これら笠，ろ過することなく， 4.1 で示した硝酸苍含吉試料びんに船上でとった。 ス パイク添加は窒蘭に輸送後行われた. 容量の違う試料 (Table 7，相模湾海水 A，B）に添加するスパイク最を 闹一とし， ${ }^{63} \mathrm{Cu} /{ }^{65} \mathrm{Cu}$ 变变光るようにした。同位体平衡 が成立するように時々かき混ぜて保存した。

\section{3 質量分析用試料調製}

試料 $50 \mathrm{ml}$ ないし $150 \mathrm{ml}$ 程度をテフロン分液湅斗に とり，0.005\% ジテゾンークロロホルム溶液 $10 \mathrm{ml}$ ずつ を用いて，2回，銅を抽出し別の分液漏斗に移す． $0.1 \mathrm{~N}$ 塩酸 $5 \mathrm{ml}$ で洗った後, $6 \mathrm{~N}$ 掹酸 $10 \mathrm{ml}$ 中に逆抽出す る.塩酸溶液をテフロンビーカーに移し窒素気流中で蒸 発乾固し, 更に $14 \mathrm{~N}$ 硝酸と $60 \%$ 過塩素酸を $0.20 \mathrm{ml}$ ずつ加え，完全に乾困させる. $0.9 \%$ リン酸 $15 \mu \mathrm{l}$ と $0.06 \%$ シリカゲル水溶液 $30 \mu \mathrm{l}$ を加えて銅化合物女溶 解し，質星分析肞韩料とする。

\section{4 質量分析と結果}

吹報1)のイオン源フィラメント電流操作汒によって質 论分析し Table 7 に示す結果を得た。例えば相模湾溜 水Aでは, 海水 $1.863 \mathrm{~kg}$ に $4.26 \mu \mathrm{g}$ の ${ }^{65} \mathrm{Cu}$ を添加し てある. 従って, スパイク源 ${ }^{65} \mathrm{Cu}$ 濃度は $2.29 \mathrm{ng} / \mathrm{g}$ で あり， $51 \mathrm{~g}$ の試料中の量は $116.8 \mathrm{ng}$ となる.これに試 料源の ${ }^{65} \mathrm{Cu}$ (結果から逆算すると $5.3 \mathrm{ng}$ ) が加わって 
$122.1 \mathrm{ng}$ となっているはずであるが，この程度の ${ }^{65} \mathrm{Cu}$ より $\left(0.32 \sim 0.51 \times 10^{-15}\right) \mathrm{A}$ の $I^{65} \mathrm{Cu}^{+}$を得ることが でき, $I^{63} \mathrm{Cu}^{+} / I^{65} \mathrm{Cu}^{+}$は 0.129 でその変動係数は 0.9 $\%$ であった. $51 \mathrm{~g}$ の海水中の銅のモル数 $x$ は $0.340 \times$ 10-9 で，21.6ng である.

しかしこの銅量には，使用薬品源の銅（Table 8, 各 種酸より合計 $1.9 \mathrm{ng})$ と，銅の抽出に伴う器具，実験 室環境よりの污染量 $2.3 \mathrm{ng}$ (Table 7 により, Amount of sample analyzed, $\mathrm{g}$ と $\mathrm{Cu}$ measured, $\mu \mathrm{g}$ の相関図 をつくり，試料の $\mathrm{g}$ 数を 0 に外そうした $\mathrm{Cu}$ measured の $\mu \mathrm{g}$ 数）の合計 $4.2 \mathrm{ng}$ のブランク值が含まれる. ブランク值を差し引いてから求めた海水中の銅濃度は $0.34 \mathrm{ppb}$ である.なお Table 7 に示したように $10^{2} \mathrm{ng}$ の ${ }^{65} \mathrm{Cu}$ より必要十分以上の $I^{65} \mathrm{Cu}^{+}$が得られること が分かる． 徉って， ${ }^{65} \mathrm{Cu}$ スパイク量を $1 / 10$ にして， $I^{63} \mathrm{Cu}^{+} / I^{65} \mathrm{Cu}^{+}$を1 に近くして測定したほうが良いと いえる.

Table 8 Contamination from reagents and laboratory environments, in $\mathrm{ng} \mathrm{Cu}$ per analysis

\begin{tabular}{lcc}
\hline & $\begin{array}{c}\text { Acid added } \\
(\mathrm{g})\end{array}$ & $\begin{array}{c}\text { Cu contamination } \\
(\mathrm{ng})\end{array}$ \\
\hline $0.1 \mathrm{~N} \mathrm{HCl}$ & 5 & 1.5 \\
$6 \mathrm{~N} \mathrm{HCl}$ & 10 & 0.3 \\
$14 \mathrm{~N} \mathrm{HNO}_{3}$ & 0.4 & 0.03 \\
$60 \% \mathrm{HClO}_{4}$ & 0.2 & 0.075 \\
Laboratory environments & & 2.3 \\
\hline
\end{tabular}

相模湾試料 A についての繰り返し分析の結果は 0.34 土0.01 ppbとなった. 試料採取量を $51 \mathrm{ml}$ より $102 \mathrm{ml}$ に，あるいはそれより大きくすることによって，ブラン ク值の影響は小さくなろうが，しかし超微量分析法之し てはブランク值を低下させるべきであり，実験室からの 污染を小さくするためのクリーン実験室を建設中であ る.

相模湾試料 B，太平洋試料についても同様な結果を得 た，海水中の他の溶存成分の影響を受けることはなかっ た。

\section{5 結 語}

狀報1)では供試海水望として $(0.5 \sim 1.0) \mathrm{kg}$ ，添加 ${ }^{65} \mathrm{Cu}$ スパイクは $4 \mu \mathrm{g}$ 程度を用いたが，分析上の諸条件 を検討した結果，佧試量は $(0.05 〜 0.15) \mathrm{kg} ，{ }^{65} \mathrm{Cu}$ スパ イクは $(0.1 〜 0.3) \mu \mathrm{g}$ で，精度を落とすことなく分析す ることが可能となった．本法の感度は，イオン源フィラ メント上 $10^{-11} \mathrm{~g}$ の銅が検出可能な $\mathrm{Cu}+$ イオンを発生
し, 精度は $I^{63} \mathrm{Cu}^{+} / I^{65} \mathrm{Cu}^{+}$の測定の変動係数として海 水試料で $(0.3 \sim 1.5) \%$ であった. 測定対象の銅量は, 数十ng のレベルであるが共存成分の影響もなく, 繰り 返し分析の精度は $3 \%$ 程度であった. 銅は海洋生態系に おいて重要な役割りを演じている重金属成分であるが， 本法はこの方面に利用できうるものと考えられる.

本法は純水, 試薬などへの応用ももちろん可能であっ て, 海水分析の際の誤差について試薬別のブランク值を 求めることができた。すなわち $0.1 \mathrm{~N}$ 塩酸より $1.5 \mathrm{ng}$, $6 \mathrm{~N}$ 塩酸より $0.3 \mathrm{ng}, 14 \mathrm{~N}$ 硝酸より $0.03 \mathrm{ng}, 60 \%$ 過 塩素酸より 0.075 の合計 $1.9 \mathrm{ng}$, ジチゾン抽出その他 実験室環境より $2.3 \mathrm{ng}$ である. 既報のブランク值 $20 \mathrm{ng}$ を低下させることはできたが，銅の測定量に対し，なお 過大といわなければならない，その解決はクリーン実験 室の建設に待た称ばならぬところであり，目下建設中で ある・

本法の感度の增大法に関しては, 質量分析計のハード ウェアの面の問題ももちろんありうることである. しか $\iota$ California Institute of Technology の Division of Geological and Planetary Science の C. C. Patterson の質量分析計（イオン加速電厅: $5000 \mathrm{~V}$ ，イオン軌道半 径 $30 \mathrm{~cm})$ によって， ${ }^{63} \mathrm{Cu} の 1 \mu \mathrm{g}, 0.5 \mu \mathrm{g}, 0.1 \mu \mathrm{g}$ より発

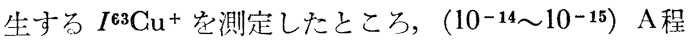
度で，日立 RMU 6 型と相違はなかった。現時点での 感度増大法の主要点は, 安定剂の量比にあると考えられ る.

本研究を行うに当たり, 大きな御援助を頂いた東京大 学海洋研究所の堀部純男, 坪四愽行雨氏とカリフォルニ ア工策大学の Dr. C. C. Patterson にお礼申し上げる. な打研究費の一部は交部省科学研究費 [特定研究: 海洋 環境における金属污染物質の分析法に関する基礎的研 究3) (研究代表者: 京都大学化学研究所重松恒信氏)] に よった.

$\left(\begin{array}{l}1975 \text { 年 } 10 \text { 月 } 1 \text { 日, 日本分析化学 } \\ \text { 会第 } 24 \text { 年会に拉いて一部発表 }\end{array}\right)$

\section{文献}

1）室住正世，阿部友二：本訫，24，337 (1975).

2) A. E. Cameron, D. H. Smith, R. L. Walker : Anal. Chem., 41, 525 (1969).

3）室住正世：海洋環境における金属污染物質の分析 法に関する基礎的研究，1974 年度特定研究報告 (1975).

$$
\hat{\imath}
$$

Isotope dilution mass spectrometry of copper in sea water (I). Masayo Murozumi, Seiji Nakamura and Kozi Iтo (Department of Applied Chemistry, Muroran Institute of Technology, 27-1, Mizumotocho, Muroran-shi, Hokkaido) 
A minute amount of copper can be accurately determined by the isotope dilution mass spectrometry using a single rhenium filament as the surface ionization device. Silica gel and phosphoric acid serve as stabilizing agents for $\mathrm{Cu}^{+}$emission. After being isotopically equilibrated with $0.1 \mu \mathrm{g}$ of ${ }^{65} \mathrm{Cu}$ spike, copper in $50 \mathrm{~g}$ of sea water is extracted into $20 \mathrm{ml}$ of $0.005 \%$ dithizone chloroform. Copper is back-extracted into $10 \mathrm{ml}$ of $6 \mathrm{~N}$ hydrochloric acid, heated to dryness and is finally treated with each $0.2 \mathrm{ml}$ of nitric acid and perchloric acid. The residue is dissolved in a mixed solution of 30 $\mu \mathrm{l}$ of $0.06 \%$ silica gel suspension water and $15 \mu \mathrm{l}$ of $0.9 \%$ phosphoric acid. An aliquot of the solution is analysed by a Hitachi RMU-6 type mass spectrometer. One tenth $\mu \mathrm{g}$ of copper usually emits stable $\mathrm{Cu}^{+}$ion beam whose current intensity is of the level of $\left(10^{-14} \sim 10^{-15}\right) \mathrm{A}$. The addition of optimum amount of stabilizing agents could increase the intensity of emitted copper ion beam by a factor of 10 . The detection limit is $10^{-11} \mathrm{~g}$ for copper. The ${ }^{63} \mathrm{Cu}^{+} /{ }^{65} \mathrm{Cu}^{+}$value is recorded with the coefficient of variation smaller than 1.5\%. Application of the method to Sagami bay water and central Pacific deep water showed that copper concentration is $(0.34 \pm 0.01) \mathrm{ppb}$ and $(0.30 \pm 0.01) \mathrm{ppb}$ in the former and $(0.33 \pm 0.02) \mathrm{ppb}$ in the latter.

(Received Apr. 12, 1976)

\section{Keywords}

\section{Copper}

Isotope dilution method

Mass spectrometry

Sea water 